\title{
JOURNAL.RU
}

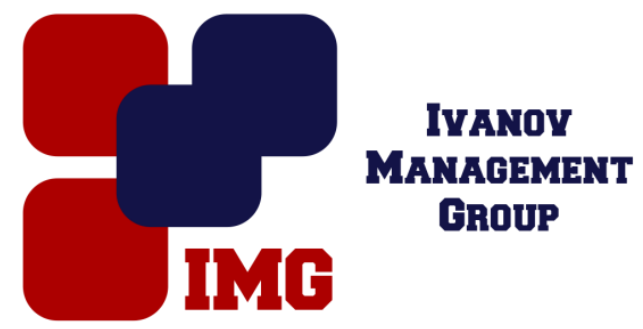

Сторожева Н.Е. Кемеровский технологический институт пищевой промыциленности (университет) Кемерово, Россия

doi: 10.18411/lj-31-05-2017-29

idsp 000001:1j-31-05-2017-29

\section{Использование педагогических технологий в процессе формирования личностных и образовательных компетенций обучающихся}

Использование педагогических технологий - эффективный способ формирования личностных и образовательных компетенций обучающихся. В образовании педагогическая технология, как правило, воплощающая принципы определенной концепции может быть представлена в трех аспектах: в научном, как часть педагогической науки, определяющая цели, содержание и методы обучения; в процессуально-описательном, как описание совокупности методов, приемов, средств; в процессуально-действенном, как реализация самого педагогического процесса, при использовании определенных средств. В процессе эксперимента в рамках преподаваемых дисциплин мы использовали различные педагогические технологии, рассматриваемые нами в процессуальноописательном и процессуально-действенном аспектах.

Мы понимаем педагогическую технологию как систему функционирования всех компонентов педагогического процесса, построенную на научной основе, запрограммированную во времени и в пространстве, направленную на достижение результатов образования [159, с. 38], личностных и образовательных компетенций. Педагогическая технология включает в себя запрограммированный процесс взаимодействия преподавателя и обучающихся, определенный педагогический замысел и цель, она обладает специфическими особенностями.

Необходимость реализации педагогических технологий четко не прописана в ФГОС СПО, как и в ФГОС высшего профессионального образования. В ФГОС высшего профессионального образования по 
специальности 20.05.01 «Пожарная безопасность» (уровень специалитета) зафиксированы требования к условиям реализации ППССЗ, где указано, что образовательная организация должна предусматривать широкое использование в учебном процессе активных и интерактивных форм проведения занятий (компьютерных симуляций, деловых и ролевых игр, разбор конкретных ситуаций, психологических и иных тренингов) в сочетании с внеаудиторной работой с целью формирования и развития профессиональных навыков обучающихся [141, с. 82]. Требования ориентируют на применение различных форм работы, которые в свою очередь в современных условиях должны быть составляющими педагогических технологий, используемых в учебном процессе. При этом нет различий в требованиях к программам среднего и высшего образования, но относительно применения педагогических технологий в образовательном процессе среднего и высшего образования различия существуют. При использовании педагогических технологий в процессе эксперимента мы опирались на работы известных российских исследователей (С. И. Беспалько, Г. К. Селевко, В. А. Сластенина, и др).

Применение педагогических технологий должно определяться содержанием образования по конкретной учебной дисциплине; в процессе эксперимента содержание формировалось в соответствии с нормативными образовательными документами и было ориентировано на достижение личностных и образовательных компетенций обучающихся. Содержание определяло, что будет формироваться, а технология определяла, как это будет формироваться.

В процессе эксперимента использовались как традиционные, так и инновационные технологии обучения: проектное обучение, проблемное обучение, интерактивное обучение. Все технологии между собой тесно взаимосвязаны и их использование происходило комплексно на разных этапах достижения результатов образования, в зависимости от особенностей обучающихся и их уровня развития; реализация всех педагогических технологий имела определенные достоинства и была направлена на достижение личностных и образовательных компетенций обучающихся.

Мы разработали рекомендации по применению методов обучения в рамках используемых педагогических технологий. Мы определили, что выбор методов и средств обучения, составляющих важную часть структуры педагогической технологии, зависел от содержания обучения, а их эффективное использование способствовало активизации учебной деятельности 
обучающихся, что в целом работало на результативность процесса формирования личностных и образовательных компетенций обучающихся.

Например, в процессе эксперимента нами были использованы методы обучения: лекция - пресс-конференция, лекция - визуализация, проблемная лекция, лекция с запланированными ошибками; решение ситуационных задач, дискуссии, индивидуальные практические задания и др. Мы разработали рекомендации по выбору методов обучения, которые включают в себя определенную последовательность этапов. Педагогом должны быть определены: - цели обучения и результаты образования, которых предположительно должны достигнуть обучающиеся; - особенности содержания и методики преподавания изучаемой дисциплиныа; - цели и задачи конкретного занятия и время, отведенное на изучение материала; - количество и сложность учебного материала; - особенности обучающихся (возрастные и познавательные); внешние условия и материальная оснащенность; - личные возможности. Использование педагогических технологий в процессе обучения имеет важное значение для формирования личностных и образовательных компетенций обучающихся.

1. Приказ Минобрнауки России от 17 августа 2015 г. N 851 «Об утверждении и введении в действие федерального государственного образовательного стандарта высшего профессионального образования по специальности 20.05 .01 «Пожарная безопасность» (уровень специалитета) [Электронный ресурс] - Режим доступа: http://www.consultant.ru/cons/cgi/online.cgi?req=doc;base=law;n=114047; dst=100001.

2. Селевко, Г. К. Энциклопедия образовательных технологий: В 2 т. Т. 1 / Г. К. Селевко. М. : НИИ школьных технологий, 2006. - 816 c. 